\title{
Intensifikasi Program Satu Sekolah Satu Buku untuk Meningkatkan Kemampuan Menulis Cerita pada Guru SD
}

\author{
Sutaji \\ SDN Tenggilis Mejoyo I Surabaya \\ Jl. Raya Jemursari No. 232, Kecamatan Tenggilis Mejoyo, Kota Surabaya \\ bapakmuizsutaji@gmail.com
}

\begin{abstract}
The goal to be achieved in this research is that teachers at SD Negeri Tenggilis Mejoyo I Surabaya have the ability to write stories in the 2021/2022 Academic Year. This action research was carried out at SD Negeri Tenggilis Mejoyo I, Tenggilis Mejoyo sub-district, Surabaya City, involving 18 teachers as research subjects from August to September 2020. This research was action research because the author who carried out the action was the head of SD Negeri Tenggilis Mejoyo I who was responsible for fully on the development of human resources in the school environment. Story writing activity is one of the most complicated teacher professional development jobs because it requires accuracy based on the formulation of indicators. The form of story writing really depends on the indicators to be measured. Each form of this story has advantages and, disadvantages, therefore the form of the story is adjusted to the indicators to be measured. Therefore, efforts are needed to improve teacher competence, especially in writing stories, one of which is through efforts to organize workshops. Workshop is a scientific meeting in a similar field (Education) to produce real work. Based on data analysis, it can be concluded from this research that the intensification of the One School One Book Program through a Workshop in writing stories is very effective. The attitudes and abilities of the teachers at Tenggilis Mejoyo I Elementary School, Tenggilis Mejoyo Subdistrict, Surabaya City have increased after the Workshop. In addition, it can also improve the ability of teachers in writing stories professionally. This can be seen in the second cycle of activities after the intensification of the One School One Book Program through the Workshop the average score obtained was 70.3. The story is said to be feasible if at least $65 \%$ of the criteria can be met. Thus, it can be stated that in the first and second cycles $100 \%$ of teachers were able to write stories that deserved to be published through the One School One Book program.
\end{abstract}

Keywords: Program Intensification, One School One Book, Teachers, Writing Stories

\begin{abstract}
Abstrak
Tujuan yang ingin dicapai dalam penelitian ini adalah agar guru-guru di SD Negeri Tenggilis Mejoyo I Surabaya memiliki kemampuan dalam menulis cerita pada Tahun Pelajaran 2021/2022. Penelitian tindakan ini dilaksanakan di SD Negeri Tenggilis Mejoyo I kecamatan Tenggilis Mejoyo Kota Surabaya dengan melibatkan 18 guru sebagai subyek penelitian pada bulan Agustus sampai dengan September 2020. Penelitian ini adalah penelitian tindakan karena penulis yang melaksanakan tindakan sebagai kepala SD Negeri Tenggilis Mejoyo I yang bertanggung jawab sepenuhnya pada pengembangan SDM di lingkungan sekolah. Kegiatan menulis cerita merupakan salah satu pekerjaan pengembangan profesi guru yang cukup rumit karena memerlukan ketelitian yang berdasarkan rumusan indikator. Bentuk penulisan cerita sangat tergantung dari indikator yang akan diukur. Masing-masing bentuk cerita ini memiliki keunggulan dan kelemahan, maka dari itu bentuk cerita disesuaikan dengan indikator yang akan diukur. Oleh karenanya dibutuhkan upaya untuk meningkatkan kompetensi guru khususnya dalam menulis cerita, salah satunya melalui upaya penyelenggaraan Workshop. Workshop adalah suatu pertemuan ilmiah dalam bidang sejenis (Pendidikan) untuk menghasilkan karya nyata. Berdasarkan analisis data, dari penelitian ini dapat ditarik kesimpulan bahwa intensifikasi Program Satu Sekolah Satu Buku melalui Workshop dalam menulis cerita sangat efektif. Sikap dan kemampuan guru di SD Negeri Tenggilis Mejoyo I Kecamatan Tenggilis Mejoyo Kota Surabaya Tahun Pelajaran 2021/2022 meningkat setelah Workshop. Selain itu, juga dapat meningkatkan pula kemampuan guru di dalam menulis cerita secara profesional. Hal ini terlihat pada kegiatan siklus kedua setelah intensifikasi Program Satu Sekolah Satu Buku melalui Workshop rata rata nilai yang diperoleh adalah 70,3. Cerita dikatakan layak apabila minimal $65 \%$ kriteria bisa terpenuhi. Dengan demikian telah dapat dinyatakan bahwa pada siklus pertama dan kedua $100 \%$ guru sudah mampu menulis cerita yang patut dipublikasikan melalui program Satu Sekolah Satu Buku.
\end{abstract}

Kata kunci: Intensifikasi Program, Satu Sekolah Satu Buku, Guru, Menulis Cerita

Copyright (c) 2021 Sutaji

Corresponding author: Sutaji 
Email Address: bapakmuizsutaji@gmail.com (Jl. Raya Jemursari No. 232, Tenggilis Mejoyo, Kota Surabaya) Received 09 September 2021, Accepted 06 October 2021, Published 19 November 2021

\section{PENDAHULUAN}

Keramaian literasi di sejumlah titik di negeri ini ternyata tidak mampu mendongkrak secara signifikan konsumsi buku masyarakat. Toko buku tidak lagi seramai ketika Harry Potter, Ayat-Ayat Cinta, dan Laskar Pelangi terbit. Hanya beberapa judul buku, yang ditulis secara konsisten oleh penulis yang menjaga kualitas karyanya, yang terus bertengger di rak buku berlabel best seller. Penjualan buku mengalami fluktuasi. Imbasnya, penerbit bermodal besar terus bertahan, penerbit bermodal kecil bertumbangan. Gerakan kolaboratif para aktivis literasi dan perbukuan pun terdengar senyap, disinyalir lantaran kurang didukung masif oleh pemerintah dan media nasional.

Minat baca masyarakat yang rendah dituding pula sebagai penyebabnya. Sejumlah media massa nasional melansir survei Unesco pada 2012 menunjukkan indeks membaca masyarakat Indonesia adalah 0,001 . Artinya, dari 1.000 orang Indonesia, hanya 1 orang yang membaca serius. Hasil tes Programme for International Student Assessment (PISA) 2012 mengenai literasi matematika, membaca, dan sains yang menempatkan Indonesia di urutan 64 dari 65 negara disurvei, makin mengokohkan asumsi tentang rendahnya minat baca masyarakat Indonesia. Terlebih, skor literasi membaca siswa Indonesia (berusia 15 tahun) itu hanya 396, jauh di bawah standar rata-rata 496.

Pemerintah yang sejak puluhan tahun berkonsentrasi pada pengentasan buta aksara (bacatulis-hitung), mulai mengubah fokus setelah penuntasan buta aksara pada 2015 melebihi target. Fokus itu bukan lagi sekadar membuat anak bisa calistung, melainkan mendorong anak memahami materi yang dibacanya. Fokus ini sesuai dengan pengertian literasi yang digunakan dalam survei PISA.

Perubahan fokus kebijakan pendidikan yang mengarah pada kecakapan abad ke-21 (literasi, kompetensi, dan karakter) diformulasikan dalam Peraturan Menteri Pendidikan dan Kebudayaan Nomor 23 Tahun 2015 tentang Penumbuhan Budi Pekerti. Permendikbud ini kemudian menginisiasi lahirnya Gerakan Indonesia Membaca dan Gerakan Literasi Sekolah. Gerakan Indonesia Membaca melingkupi gerakan literasi di ranah masyarakat dan keluarga, sementara Gerakan Literasi Sekolah mencakup gerakan literasi di lingkungan sekolah.

Permendikbud yang ditandatangani oleh Anies Baswedan pada tahun 2015 ini memberi arah tersendiri dalam proses mencapai tujuan, yang kemudian membedakannya dengan implementasi kebijakan pendidikan sebelumnya. Jika sebelumnya kebijakan pendidikan kuat mengesankan pemerintah sebagai pemain utama, kini pelaksanaan kebijakan dilakukan secara bersama dalam sebuah gerakan yang melibatkan pemerintah, pemerintah daerah, masyarakat, dan keluarga.

Penerbitan Peraturan Menteri Pendidikan dan Kebudayaan Nomor 23 Tahun 2015 tentang Penumbuhan Budi Pekerti merupakan pintu masuk bagi program baru Kemendikbud setelah bertahuntahun bergelut dalam program pengentasan buta aksara, yaitu literasi. Saya memandang, momen ini 
adalah angin segar menuju perubahan substansial dalam pembelajaran di sekolah. Selama ini, fokus pembangunan dunia pendidikan lebih banyak tertuju pada perluasan akses pendidikan. Perhatian terhadap kualitas pendidikan sudah tampak, namun masih terasa ada yang kurang.

Sebagai Kepala Sekolah, bertahun-tahun saya mengidentifikasi bahwa kekurangan itu terletak pada perhatian dalam proses pembelajaran di kelas. Interaksi guru dan siswa, dalam proses belajar mengajar, seharusnya mendapat porsi besar dalam kebijakan di dunia pendidikan. Sebab dari dalam kelaslah perubahan itu dimulai, kemudian merambah ke lingkungan keluarga, dan memengaruhi kehidupan masyarakat.

Sejatinya paradigma baru abad 21 yang mengutamakan kolaborasi, bukan kompetisi, menjadi sarana menjalin komunikasi dengan berbagai pemangku kepentingan untuk merumuskan kebijakan secara bersama-sama. Gerakan yang menjadi ciri pengembangan literasi menjadi energi tersendiri yang mendorong Pemerintah Pusat, Pemerintah Daerah, praktisi, akademisi, pegiat literasi, dan lembaga swadaya masyarakat untuk duduk satu meja merumuskan kehendak bersama.

Di tahun ke-5 Gerakan Literasi Sekolah (2015 - 2020) berjalan, penulis sebagai Kepala Sekolah disibukkan dengan banyak sekali kegiatan yang menghimpun sekian jumlah kalangan dalam satu meja. Kami berdiskusi, berbagi informasi, dan menetapkan strategi pencapaian yang tidak hanya melibatkan sekolah, namun juga keluarga dan masyarakat. Bagaimanapun, Gerakan Literasi Sekolah (GLS) akan berjalan optimal jika melibatkan unsur keluarga dan masyarakat. Literasi, akhirnya, menjadi jembatan bagi implementasi tripusat pendidikan.

Dalam bukunya Suara dari Marjin (2017), Sofie Dewayani dan Pratiwi Retnaningdyah menyebut literasi seperti fashion. Ia hiruk pikuk di suatu masa dan kembali sepi ketika masa itu telah mencapai klimaksnya. Kondisi ini semestinya tidak menjadi hantu yang ditakuti. Bahkan sebaiknya dijadikan introspeksi sejauh mana gerakan literasi pada 'suatu masa' mampu mengubah pola pikir dan perilaku masyarakat menjadi lebih literat.

Kini, setelah 'resmi' menjadi program pemerintah, gerakan literasi memikul tanggung jawab besar tidak hanya meneruskan pengurangan penyandang buta aksara, melainkan mengusung perubahan pola pikir dan perilaku masyarakat abad 21. Pola pikir yang dimaksud adalah kemampuan berpikir tingkat tinggi (High Order Thinking Skills) seperti berpikir kritis, kreatif, komunikatif, dan kolaboratif.

Sasaran perubahan tidak lagi menyempit di kalangan orang-orang yang kurang pendidikan. Orang-orang berpendidikan (mengenyam bangku sekolah) menjadi sasaran utama perubahan karena di kepala merekalah roda peradaban berputar. Pelaku kerusakan, di abad ini, bukanlah berasal dari orang-orang miskin tidak berpendidikan. Sebaliknya, penyumbang kerusakan terbesar terhadap ekosistem bumi dan kehidupan sosial-masyarakat adalah orang-orang miskin moral namun berpendidikan.

Penelitian ini merangkum sekaligus menginformasikan secara singkat dan padat beragam kegiatan yang telah dilakukan Ditjen Dikdasmen seputar pelaksanaan GLS. Jarang sekali ada buku 
yang mengupas proses di balik sebuah kebijakan dan memotretnya dari dekat, mengungkap kegelisahan dan harapan para pelaku dengan menjaga kredibilitas dan transparansi. Dapat dikatakan, buku ini membuka “dapur” Ditjen Dikdasmen menjelang dan setelah program GLS muncul.

Dinas Pendidikan Kota Surabaya mematangkan penerbitan 1.000 buku karya para guru seSurabaya. Demi mematangkan konsep dan teknis pengumpulannya, mereka menggelar rapat koordinasi dan sosialisasi via daring. Sosialisasi itu diikuti oleh Ikatan Guru Taman Kanak-kanak Indonesia (IGTKI), Kelompok Kerja Kepala Sekolah (K3S) SD negeri dan swasta, Musyawarah Kerja Kepala Sekolah (MKKS) SMP negeri dan swasta, penilik, pengawas, dan koordinator wilayah. Rencananya, ribuan buku itu akan diluncurkan bertepatan dengan puncak peringatan Hari Guru Nasional pada 25 November 2020 mendatang.

Oleh karena itu, penulis sebagai Kepala Sekolah berupaya untuk memaksimalkan pelaksanaan dan hasil dari program tersebut melalui penelitian tindakan dengan judul: "Intensifikasi Program Satu Sekolah Satu Buku untuk Meningkatkan Kemampuan Menulis Cerita pada Guru SD Negeri Tenggilis Mejoyo I Surabaya Semester Gasal Tahun Pelajaran 2021/2022”.

\section{Kompetensi Guru}

Kemampuan guru dapat ditilik dari beberapa kompetensi yang terwujud dalam bentuk penguasaan pengetahuan dari perbuatan secara profesional dalam menjalankan fungsi sebagai guru. Hal tersebut dapat tercermin dari beberapa hal sebagai berikut:

1. Profesionalisme guru

Guru adalah tenaga fungsional yang bertugas khusus untuk mengajar, mendidik, melatih, dan menilai hasil pembelajaran siswa serta efektifitas mengajar guru. Tugas guru adalah profesi maka dari itu diharapkan dapat melaksanakan tugas dengan baik. Karena profesi menurut Sikun Pribadi dalam bukunya Etty menyatakan bahwa profesi itu pada hakekatnya suatu pernyataan atau janji terbuka, bahwa seseorang akan mengabdikan dirinya pada suatu jabatan atau pekerjaan dalam arti biasa (Etty, 2003:2). Profesi merupakan pernyataan atau janji terbuka oleh seorang profesional. Dengan demikian pernyataan profesional mengandung makna yang terbuka, sungguh-sungguh yang ke luar dari lubuk hatinya dan mengandung norma atau nilai nilai yang etis, sehingga pernyataan yang dibuatnya baik bagi orang lain juga baik bagi dirinya.

2. Komitmen Guru

Kewajiban guru dalam melaksanakan tugas hendaknya disiplin, obyektif, jujur, bertanggung jawab, kreatif, inovatif serta berkinerja. Profesional dan komitmen guru menurut Flanangan dalam hand out oleh Maba menyebutkan ada empat dimensi antara lain : Dimensi 1, dimensi 2, dimensi 3, dimensi 4 (Maba : 2007 : 2). Dimensi 1 ( P : + dan $\mathrm{K}:$-) adalah guru mampu mempersiapkan bahan ajar ( RPP ), pintar menyajikan bahan ajar sehingga siswa mengerti, tetapi kurang disiplin ( suka terlambat, malas, subyektif, sore memberi les, malam hari tidak jelas pekerjaannya ). Dimensi 2 ( P : + dan K : + ) adalah guru mampu menyusun RPP dan terampil menyajikan bahan ajar. Guru idial ( pintar mengajar, sistematis, rajin, disiplin, obyektif, guru 
selalu ada di hati siswa. Bila tidak ngajar doa siswa baik (semoga selamat, semoga dilindungi Tuhan, dimurahkan rejekinya oleh Tuhan, dll). Dimensi 3 (P :-dan K : -) adalah guru kurang mampu menyusun RPP, kurang terampil menyajikan bahan ajar, siswa jadi bingung, guru malas, subyektif, kurang pas jadi guru, lebih cocok alih profesi. Guru hanya dihina siswa, bila tidak masuk doa siswa yang jelek-jelek. Dimensi 4 (P:-dan K : +) adalah guru kurang mampu menyusun RPP, kurang terampil menyajikan bahan ajar, guru rajin, disiplin dan obyektif serta selalu mengutamakan kepentingan siswa (kombinasi matreo sentrisme dengan paedo sentrisme).

\section{Menulis Cerita}

Menulis merupakan suatu keterampilan berbahasa yang dipergunakan untuk berkomunikasi secara tidak langsung, tidak tatap muka dengan orang lain (Tarigan, 1986:3). Komunikasi tidak langsung ini dilakukan dengan menggunakan media tulis, dengan menggunakan lambang-lambang bahasa.

Wiyanto (2005:96) mengemukakan bahwa menulis cerita harus banyak berkhayal karena cerita memang karya fiksi yang berbentuk prosa. Peristiwa-peristiwa yang terjadi dalam cerita hanya direkayasa pengarangnya. Demikian pula para pelaku yang terlibat dalam peristiwa itu. Waktu, tempat, dan suasana terjadinya peristiwa pun hanya direka-reka oleh pengarangnya. Oleh karena itu, cerita (dan semua cerita fiksi) disebut cerita rekaan.

Cerita dalam cerita meskipun khayal, ceritanya masih masuk akal sehingga mungkin saja terjadi. Bahan baku cerita memang bisa berasal dari kisah yang benar-benar terjadi dalam masyarakat. Bisa juga cerita itu berasal dari kisah yang benar-benar dialami sendiri oleh pengarangnya yang diolah sedemikian rupa dalam bentuk cerita menjadi cerita fiksi, cerita khayal, atau cerita rekaan. Namun, ada beberapa cerita yang ceritanya tidak masuk akal, ceritanya benar-benar hasil imajinasi pengarangnya yang jauh dari kenyataan. Hartig (dalam Tarigan 1982:24) menyebutkan tujuan menulis sebagai berikut:

1. Assignment purpose (tujuan penugasan)

Tujuan penugasan ini sebenarnya tidak mempunyai tujuan sama sekali. Penulis menulis sesuatu karena ditugaskan, bukan atas kemauannya sendiri(misalnya para siswa yang diberi tugas merangkum buku; sekretaris yang ditugaskan membuat laporan, notulen rapat).

2. Altruistik purpose (tujuan altruistik).

Penulis bertujuan untuk menyenangkan para pembaca, menghindarkan kedukaan para pembaca, ingin menolong para pembaca memahami, menghargai perasaan dan penalarannya, ingin membuat hidup para pembaca lebih menyenangkan dengan karyanya itu

3. Persuasive purpose (tujuan persuasif)

Tulisan yang bertujuan meyakinkan para pembaca akan kebenaran gagasan yang diutarakan

4. Informational purpose (tujuan informasional, tujuan penerangan)

Tulisan yang bertujuan memberi informasi atau keterangan/penerangan kepada para pembaca 
5. Self-expressive purpose (tujuan pernyataan diri)

Tulisan yang bertujuan memperkenalkan atau menyatakan diri sang pengarang kepada pembaca.

6. Creative purpose (tujuan kreatif)

Tujuan ini erat hubungannya dengan tujuan pernyataan diri. Tetapi "keinginan kreatif" di sini melebihi pernyataan diri, dan melibatkan dirinya dengan keinginan mencapai norma artistik, atau seni yang ideal, seni idaman. Tulisan yang bertujuan mencapai nilai-nilai artistik, nilai-nilai kesenian.

7. Problem-solving purpose (tujuan pemecahan masalah).

Dalam tulisan seperti ini sang penulis ingin memecahkan masalah yang dihadapi. Sang penulis ingin menjelaskan, menjernihkan serta menjelajahi serta meneliti secara cermat pikiran-pikiran dan gagasan-gagasannya sendiri agar dapat dimengerti dan diterima oleh para pembaca.

Cerita tersusun atas unsur-unsur pembangun cerita yang saling berkaitan erat antara satu dengan yang lainnya. Keterkaitan antara unsur-unsur pembangun cerita tersebut membentuk totalitas yang bersifat abstrak. Koherensi dan keterpaduan semua unsur cerita yang membentuk sebuah totalitas amat menentukan keindahan dan keberhasilan cerita sebagai suatu bentuk ciptaan sastra. Unsur-unsur dalam cerita terdiri atas:

1. Alur atau Plot

Pengertian alur dalam cerita pendek atau dalam karya fiksi pada umumnya adalah "rangkaian cerita yang dibentuk oleh tahapan-tahapan peristiwa sehingga menjalin suatu cerita yang dihadirkan oleh para pelaku dalam suatu cerita" (Aminuddin 1987:83). Menurut Suharianto (1987:28) alur atau plot yakni cara pengarang menjalin kejadian-kejadian secara beruntun dengan memperhatikan hukum sebab akibat sehingga merupakan kesatuan yang padu, bulat, dan utuh"

2. Tokoh dan Penokohan

Tokoh cerita (charakter), menurut Abrams (dalam Nurgiyantoro 1994:165), adalah orang-orang yang ditampilkan dalam suatu karya naratif. Atau drama, yang oleh pembaca ditafsirkan memiliki kualitas moral dan kecenderungan tertentu seperti yang diekspresikan dalam ucapan dan apa yang dilakukan dalam tindakan. Tokoh adalah individu rekaan yang mengalami peristiwa dalam cerita atau perlakuan dalam cerita (Sudjiman dalam Faozan 2002:20). Tokoh dalam cerita bersifat fiktif. Sudjiman juga mengemukakan pembagian tokoh dalam cerita dapat dilihat dari fungsi dan cara penampilannya.

3. Latar atau Setting

Latar atau setting adalah tempat, waktu, dan suasana terjadinya peristiwa dalam cerita (Wiyanto 2005:82). Selanjutnya Nurgiyantoro (2005:217) menyebutkan bahwa latar memberikan pijakan cerita secara konkret dan jelas. Hal ini penting untuk memberikan kesan realistis kepada pembaca, meciptakan suasana tertentu yang seolah-olah sungguh-sungguh ada dan terjadi. Setting bukan hanya menunjukkan tempat dan waktu tertentu tetapi juga hal-hal yang hakiki dari 
suatu wilayah, sampai pada macam debunya, pemikiran rakyatnya, kegilaan mereka, gaya hidup mereka, kecurigaan mereka dan sebagainya (Sumardjo 1991:76).

4. Sudut Pandang atau Point of View

Yang dimaksud titik pandang atau point of view adalah cara pengarang menampilkan para pelaku dalam cerita yang dipaparkan (Aminuddin 1987:90). Sudut pandang atau titik kisah ( point of view) adalah posisi pencerita (pengarang) terhadap kisah yang diceritakan (Wiyanto 2005:83). Point of view pada dasarnya adalah visi pengarang artinya sudut pandangan yang diambil pengarang untuk melihat suatu kejadian cerita (Sumardjo 1986:82). Selain itu Nurgiyantoro (2005: 248) juga menyebutkan bahwa sudut pandang pada hakikatnya merupakan strategi, teknik, dan siasat, yang secara sengaja dipilih pengarang untuk mengemukakan gagasan dan ceritanya.

5. Gaya

Gaya erat hubungannya dengan nada cerita. Gaya merupakan pemakaian bahasa yang spesifik dari seorang pengarang. Pengertian gaya dikemukakan oleh beberapa pengarang seperti yang tersebut berikut; "gaya bahasa adalah cara pengarang menggunakan bahasa untuk menghasilkan karya sastra"(Wiyanto 2005:84). Aminuddin (1987:72) mengemukakan bahwa gaya bahasa mengandung pengertian cara pengarang menyampaikan gagasannya dengan menggunakan media bahasa yang indah dan harmonis serta mampu menuansakan makna dan suasana yang dapat menyentuh daya intelektual dan emosi pembaca.

6. Tema

Tema adalah ide cerita (Sumardjo 1986:56). Selanjutnya Suharianto (1982:28) mengatakan bahwa tema sering disebut juga dasar cerita; yakni pokok permasalahan yang mendominasi suatu karya sastra. Ia terasa dan mewarnai karya sastra tersebut dari halaman pertama hingga halaman terakhir. Hakikatnya tema adalah permasalahan yang merupakan titik tolak pengarang dalam menyusun cerita atau karya sastra tersebut, sekaligus merupakan permasalahan yang ingin dipecahkan pengarang dengan karyanya itu.

7. Amanat

Karya sastra selain berfungsi sebagai hiburan bagi pembacanya, juga berfungsi sebagai sarana pendidikan. Dengan kata lain, pengarang selain untuk menghibur pembaca (penikmat) juga ingin mengajari pembaca. Ajaran yang ingin disampaikan pengarang itu dinamakan amanat. Amanat adalah unsur pendidikan, terutama pendidikan moral, yang ingin disampaikan oleh pengarang kepada pembaca lewat karya sastra yang ditulisnya (Wiyanto 2005:84). Menurut Suharianto (1982:70) "amanat ialah nilai-nilai yang ada dalam cerita". 


\section{Intensifikasi Program Satu Sekolah Satu Buku}

Sekolah, akhirnya, menjadi sentral aktivitas di antara tripusat pendidikan itu. Sebab masyarakat dan kebanyakan keluarga Indonesia masih menyerahkan pendidikan anak-anak kepada sekolah. Sekolah masih dianggap sebagai tempat efektif dalam membentuk nilai-nilai baik dalam diri anak. Dengan demikian, beragam aktivitas dan kebijakan di sekolah sedianya berimbas pada perubahan di lingkup keluarga dan masyarakat.

Penerbitan karya tulis berupa buku merupakan bentuk penghargaan literasi oleh Pemerintah Kota Surabaya melalui Dinas Pendidikan kepada masyarakat, khususnya guru. Tidak sekadar menerbitkan, Pemerintah Kota Surabaya juga mendistribusikannya ke tempat-tempat yang mudah diakses masyarakat seperti perpustakaan daerah, perpustakaan sekolah, Taman Bacaan Masyarakat, dan toko buku. Sosialisasi dan eksplorasi karya berupa bedah buku dan seminar juga dapat dilakukan dengan menggandeng penerbit, komunitas literasi, dan pegiat literasi. Dengan begitu, ide-ide dan pengalaman berharga seseorang dapat dipelajari dan dicontoh orang lain.

Program menulis yang digalakkan di sekolah ini bernama 'Satu Sekolah Satu Buku. Program literasi ini memfasilitasi guru, untuk sementara waktu, di satu sekolah untuk menerbitkan satu buku kumpulan cerita. Tidak sekadar membantu menerbitkan, tapi program ini juga membimbing para guru sejak awal menulis hingga buku cetak ada dalam pelukan mereka.

Dinas Pendidikan Kota Surabaya mematangkan penerbitan 1.000 buku karya para guru seSurabaya. Demi mematangkan konsep dan teknis pengumpulannya, mereka menggelar rapat koordinasi dan sosialisasi via daring. Sosialisasi itu diikuti oleh Ikatan Guru Taman Kanak-kanak Indonesia (IGTKI), Kelompok Kerja Kepala Sekolah (K3S) SD negeri dan swasta, Musyawarah Kerja Kepala Sekolah (MKKS) SMP negeri dan swasta, penilik, pengawas, dan koordinator wilayah. Rencananya, ribuan buku itu akan diluncurkan bertepatan dengan puncak peringatan Hari Guru Nasional pada 25 November 2020 mendatang.

Kepala Dinas Pendidikan Kota Surabaya Supomo menuturkan, demi mewujudkan Kota Surabaya sebagai Kota Literasi, maka pihaknya membuat Program Sasek Sabu (Satu Sekolah Satu Buku). Buku-buku ini adalah karya tulis para guru mulai dari jenjang TK, SD, dan SMP se-Kota Surabaya, serta karya tulis dari pengawas dan penilik sekolah.

Berdurasi selama delapan minggu, program Satu Sekolah Satu Buku ini diawali dari tahapan seleksi. Setelah peserta dinyatakan lolos, berikutnya akan dilakukan one day Workshop. Pada tahap ini, peserta bakal dibekali dengan materi yang berhubungan dengan menulis buku.

Tak hanya sampai di situ, program ini masih dilanjutkan dengan bimbingan mengenai proses penerbitan buku. Selanjutnya, tahap eksekusi, di mana guru mulai menuliskan cerita mereka. Di sini mereka diberi kebebasan menuangkan setiap ide yang ada dalam kepala mereka. Tahap akhir yaitu proses penerbitan.

Intensifikasi program Satu Sekolah Satu Buku dilakukan melalui Metode Workshop, yaitu 
metode gabungan antara metode ekspositori (ceramah) dengan kooperatif. Karakteristik dari Metode Workshop sesuai dengan beberapa teori belajar yang diantaranya adalah teori belajar David P. Ausuabel, Bruner dan Viogotsky. Ketiga teori belajar ini berfokus pada proses ekspositori, proses menggunakan alat peraga dan berbasis kegiatan.

Metode ini menggabungkan beberapa metode pembelajaran. Metode Workshop dibagi menjadi tiga tipe yaitu Traditional Classes - Real Workshop (TC - RW), Traditional Classes Workshop (TC - VW), dan Traditional Classes - Real Workshop - Workshop (TC - RW - VW). Oleh karenanya dapat dikatakan bahwa Metode Workshop adalah gabungan dari beberapa metode yang berkenaan dengan cara guru mengadopsi konsep. Sintaknya meliputi sintaks model pembelajaran ekspositori, koperatif-inkuiri-solusi-Workshop, dan Workshop menggunakan computerinternet.

Dalam penelitian ini, Metode Workshop yang dimaksud adalah tipe pertama yaitu traditional classes - real Workshop (TC - RW). Metode Traditional Classes ialah cara pembelajaran secara tradisional. Yang dimaksud metode secara tradisional ialah metode dengan metode ekspositori. Sedangkan pembelajaran Real Workshop ialah pembelajaran dengan bantuan media komputer.

Penerapan metode ekspositori sudah biasa dilakukan oleh guru (Wahyudin, 1999), sehingga guru tidak akan terlalu kaget dengan pelaksanaan proses pembelajaran yang baru. Sedangkan proses pelaksanaan pembelajaran dengan komputer diharapkan dapat membuat siswa memahami materi lebih dalam dan mengalami proses pembelajaran materi secara langsung.

Pada Pelaksanaannya metode ekspositori memiliki prosedur-prosedur pelaksanaan, secara garis besar digambarkan oleh Wina Sanjaya (2008) sebagai berikut:

1. Persiapan (Preparation)

Tahap persiapan berkaitan dengan mempersiapkan siswa untuk menerima materi Workshop. Dalam metode ekspositori, keberhasilan pelaksanaan sangat bergantung pada langkah persiapan.

2. Penyajian (Presentation)

Tahap penyajian adalah langkah penyampaian materi Workshop sesuai dengan persiapan yang telah dilakukan. Hal yang harus diperhatikan adalah bagaimana materi tersebut dapat dengan mudah ditangkap dan dipahami oleh guru. Oleh sebab itu, ada beberapa hal yang harus diperhatikan dalam pelaksanaan langkah ini diantaranya : Penggunaan bahasa, intonasi suara, Menjaga kontak mata dengan guru, serta menggunakan kemampuan untuk menjaga agar suasana tetap hidup dan menyenangkan.

3. Korelasi (Correlation)

Tahap korelasi adalah langkah yang dilakukan untuk memberikan makna terhadap materi Workshop, baik makna untuk memperbaiki struktur pengetahuan yang telah dimiliki siswa maupun makna untuk meningkatkan kualitas kemampuan berpikir dan kemampuan motorik guru.

4. Menyimpulkan (Generalization)

Menyimpulkan adalah tahapan untuk memahami inti (core) dari materi pelajaran yang telah 
disajikan. Sebab melalui langkah menyimpulkan, guru dapat mengambil inti sari dari proses penyajian. Menyimpulkan berarti pula memberikan keyakinan kepada guru tentang kebenaran suatu paparan.

5. Mengaplikasikan (Aplication)

Tahap aplikasi adalah langkah unjuk kemampuan guru setelah beberapa tahap Workshop. Langkah ini merupakan langkah yang sangat penting dalam proses ekspositori. Sebab melalui langkah ini penyaji akan dapat mengumpulkan informasi tentang penguasaan dan pemahaman guru terhadap materi Workshop. Teknik yang biasa dilakukan pada langkah ini diantaranya, dengan membuat tugas yang relevan, serta dengan memberikan tes materi yang telah diajarkan untuk dikerjakan oleh guru.

\section{METODE}

\section{Setting Penelitian}

Penelitian Tindakan Sekolah (PTS) merupakan suatu proses dinamis yang berlangsung dalam satu atau lebih siklus, dan masing-masing siklus terdiri dari empat momen (fase) dalam spiral perencanaan, tindakan (action), observasi, dan refleksi yang oleh Kemmis dan McTaggart (1988) diilustrasikan dalam model PTS spiral. Jumlah siklus dalam satu penelitian tergantung pada kebutuhan. Siklus pertama bisa diulangi menjadi siklus kedua, yang kemudian diulangi lagi menjadi siklus ketiga dan selanjutnya hingga penulis menganggap hasil yang ada sudah memuaskan dan saatnya untuk menghentikan penelitian. Disarankan agar satu PTS dilaksanakan minimal dalam dua siklus, karena hasil refleksi siklus pertama, sedikit atau banyak, akan memberikan manfaat kepada tindakan di siklus kedua.

Dalam praktik, Kemmis dan McTaggart menyatakan model ini tidak boleh digunakan secara kaku, karena dalam kenyataan proses rencana-tindakan-observasi-refleksi tersebut tidak berlangsung serapi model tersebut. Fase-fase itu biasanya berlangsung tumpang tindih. Dengan demikian penulis dapat memperbaiki strategi tersebut secara optimal sehingga pengimplementasian strategi revisi ini nantinya dapat mencapai semua target keberhasilan. Strategi yang sudah diperbaiki (revised strategy) inilah yang menjadi fase perencanaan (plan) pada siklus berikutnya, yang nantinya diimplemetasikan, diobservasi, dan direfleksi kembali. Siklus tersebut dapat diulang beberapa kali hingga seluruh kriteria keberhasilan tercapai. Jumlah siklus tidak dapat diprediksi pada awal penelitian. Jika setelah siklus pertama semua kriteria keberhasilan dapat dicapai maka penelitian dapat dihentikan. Namun selama kriteria-kriteria keberhasilan itu belum tercapai, revisi terhadap strategi perlu dilakukan dan siklus berikutnya dilaksanakan.

\section{Subyek Penelitian}

Subyek penelitian tindakan ini adalah 18 Guru di SD Negeri Tenggilis Mejoyo I Surabaya yang masih aktif pada tahun pelajaran 2021/2022. Pelaksanaan penelitian dijadwalkan oleh penulis dengan rincian jadwal sebagai berikut: 
Tabel 1. Waktu Pelaksanaan Tindakan

\begin{tabular}{|l|l|c|c|c|}
\hline \multirow{2}{*}{ No } & \multicolumn{2}{|c|}{ Jenis Kegiatan } & \multicolumn{3}{c|}{ Bulan/Minggu } \\
\cline { 3 - 5 } & & Agt & Sep & Okt \\
\hline 1 & Konsultasi dengan pengawas. & M1 & & M3 \\
\hline 2 & Mengajukan proposal penelitian. & M1 & & \\
\hline 3 & Menyiapkan instrumen penelitian. & M1 & M1 & \\
\hline 4 & Pra program intensifikasi. & M1 & & \\
\hline 5 & Sosialisasi program intensifikasi. & M1 & & \\
\hline 6 & Pelaksanaan siklus I. & M1-3 & & \\
\hline 7 & Refleksi siklus I. & M4 & & \\
\hline 8 & Pelaksanaan siklus II. & & M1-3 & \\
\hline 9 & Refleksi siklus II. & & M4 & \\
\hline 10 & Menyusun laporan tindakan. & & & M1-2 \\
\hline
\end{tabular}

\section{Teknik Pengumpulan Data}

Pengumpulan data PTS biasanya dilakukan dengan menggunakan banyak cara dari berbagai sumber sehingga dikatakan bahwa pengumpulan datanya menggunakan triangulasi. Menurut Mills (2003:71), dari segi teknik pengumpulan data kualitatif, ada tiga teknik yang dapat dipilih oleh penulis untuk mengumpulkan data yaitu; (1) experiencing, pengumpulan data melalui pengalaman sendiri, terlibat dan berpartisipasi dalam kegiatan atau membuat catatan lapangan, (2) enquiring, pengumpulan data pertanyaan oleh penulis, dan (3) examining, pengumpulan data melalui pembuatan dan pemanfaatan catatan yang dapat berupa dokumen arsip dan jurnal.

\section{Validasi Data}

Validasi data juga dapat ditempuh dengan penganekaragaman alat pengumpul data. Semakin banyak data yang menguatkan didapat dengan alat pengumpul data yang berbeda maka data tersebut semakin valid. Sedangkan untuk memperoleh data yang mendukung keshahihan, serta sesuai denga fokus permasalahan dan tujuan yang hendak dicapai pada penelitian digunakan teknik validasi data. Konsep validitas dalam aplikasinya untuk penelitian tindakan mengacu kepada kredibilitas dan derajat keterpecayaan dari hasil penelitian. Salah satu langkah dalam prosedur untuk mendapatkan derajat kepercayaan ialah melalui validasi, yang dalam penelitian kualitatif disukai dengan istilah verifikasi. Menurut Borg dan Gall (2003) terdapat lima tahap kriteria validitas, yaitu: validitas hasil, proses, demokratis, katalis, dan dialog.

Berdasarkan tahapan kriteria validitas, maka dalam penelitian ini validitas data menggunakan teknik Triangulasi Data. Triangulasi data yaitu mengecek keabsahan (validasi) data dengan mengkonfirmasikan data yang sama dari sumber yang berbeda untuk memastikan keabsahan (derajat kepercayaan). 


\section{Teknik Analisa Data}

Teknik analisis data adalah kegiatan mencermati, menguraikan, dan mengkaitkan setiap informasi yang terkait dengan kondisi awal, proses belajar, dan hasil pembelajaran untuk memperoleh simpulan tentang keberhasilan indakan perbaikan pembelajaran. Pengumpulan data yang ada, selanjutnya dianalisis. Untuk menganalisis data tersebut, penulis memerlukan analisis data yang sesuai agar data yang diperoleh dapat dipertanggungjawabkan, maka dalam penelitian ini penulis menggunakan analisis data kualitatif dan analisis data kuantitatif.

Analisis data kualitatif pada penelitian ini diperoleh dari hasil observasi yang dilakukan oleh penulis yang memuat gambaran tingkat efektivitas intensifikasi Program Satu Sekolah Satu Buku melalui Workshop terhadap kemampuan guru dalam Menulis Cerita pada setiap siklus. Analisis data kuantitatif diperoleh dari nilai observasi pada kemampuan guru dalam Menulis Cerita, di mana guru secara individu dapat dikatakan berhasil apabila sekurang-kurangnya menguasai $65 \%$ kemampuan yang dinilai pada lembar observasi.

Data pengamatan dianalisis dengan menghitung rata-rata pada setiap siklus yang dilaksanakan menggunakan rumus:

$$
\text { Nilai }=\frac{\text { totalskorerolehan }}{\text { totalskor }} \times 100
$$

Selanjutnya nilai rata-rata tersebut diklasifikasikan dengan kriteria sebagai berikut :

1. $86-100=$ sangat baik $(\mathrm{A})$

2. $66-85=$ baik $(B)$

3. 55-65 = cukup $(\mathrm{C})$

4. $44-55=$ kurang $(\mathrm{D})$

5. 25-45 = sangat kurang $(\mathrm{E})$

\section{Indikator Kinerja}

Adapun indikator kinerja yang menjadi tolak ukur penilaian kuantitatif pada penelitian ini berdasarkan kajian pustaka pada bab 2 dapat penulis jabarkan pada tabel berikut:

Tabel 2. Indikator Kemampuan Menulis Cerita

\begin{tabular}{|c|l|}
\hline No & \multicolumn{1}{|c|}{ Unsur yang Dinilai } \\
\hline 1 & Sudut pandang \\
\hline 2 & Plot \\
\hline 3 & Gaya bahasa \\
\hline 4 & Amanat \\
\hline
\end{tabular}




\section{$5 \quad$ Kesiapan mental}

\section{HASIL DAN DISKUSI}

\section{Deskripsi Siklus I}

Pada bagian ini dikemukakan hasil penelitian siklus I sesuai dengan proposal semua subyek penelitian terdiri dari guru guru SD Negeri Tenggilis Mejoyo I Surabaya Tahun Pelajaran 2021/2022 yang berjumlah 18 orang. Semua guru tersebut sudah siap dengan perlengkapannya untuk mengikuti Kegiatan Intensifikasi Program Satu Sekolah Satu Buku melalui Workshop.

Untuk menjawab masalah penelitian diadakan dua siklus sesuai dengan PTS, tetapi setelah diadakan penelitian ternyata tidak sampai pada dua siklus. Pada siklus I semua guru dimasing-masing kelompok mata pelajaran sudah bisa menyelesaikan sesuai dengan ketentuan yang dipersyaratkan.

Berdasarkan hasil penelitian Kemampuan Menulis Cerita, pengamatan (observasi) yang dilakukan pada siklus I maka diperoleh hasil penelitian disampaikan dalam bentuk tabel.

Tabel 3. Hasil Observasi Siklus I (sebelum diadakan intensifikasi program)

\begin{tabular}{|c|c|c|c|c|c|c|c|}
\hline \multirow[b]{2}{*}{ No } & \multirow{2}{*}{$\begin{array}{l}\text { Nama Guru } \\
\text { (Kode) }\end{array}$} & \multicolumn{4}{|c|}{ Unsur Cerita yang Dinilai } & \multirow[b]{2}{*}{$\begin{array}{c}\text { Kesiapan } \\
\text { Mental }\end{array}$} & \multirow[b]{2}{*}{$\begin{array}{l}\text { Hasil } \\
\text { akhir }\end{array}$} \\
\hline & & $\begin{array}{c}\text { Sudut } \\
\text { Pandang }\end{array}$ & Plot & $\begin{array}{c}\text { Gaya } \\
\text { Bahasa }\end{array}$ & Amanat & & \\
\hline 1 & $\mathrm{~A}$ & 3 & 3 & 3 & 4 & 3 & 80 \\
\hline 2 & B & 3 & 3 & 3 & 4 & 3 & 80 \\
\hline 3 & $\mathrm{C}$ & 3 & 3 & 2 & 4 & 3 & 75 \\
\hline 4 & $\mathrm{D}$ & 3 & 3 & 3 & 4 & 4 & 85 \\
\hline 5 & $\mathrm{E}$ & 3 & 3 & 3 & 4 & 3 & 80 \\
\hline 6 & $\mathrm{~F}$ & 3 & 3 & 4 & 4 & 3 & 85 \\
\hline 7 & $\mathrm{G}$ & 3 & 3 & 3 & 4 & 3 & 80 \\
\hline 8 & $\mathrm{H}$ & 3 & 3 & 3 & 4 & 3 & 80 \\
\hline 9 & I & 3 & 3 & 2 & 4 & 3 & 75 \\
\hline 10 & $\mathrm{~J}$ & 3 & 3 & 3 & 4 & 4 & 85 \\
\hline 11 & $\mathrm{~K}$ & 3 & 3 & 3 & 4 & 3 & 80 \\
\hline 12 & $\mathrm{~L}$ & 3 & 3 & 4 & 4 & 3 & 85 \\
\hline 13 & $\mathrm{M}$ & 3 & 3 & 3 & 4 & 3 & 80 \\
\hline 14 & $\mathrm{~N}$ & 3 & 3 & 3 & 4 & 3 & 80 \\
\hline & Rata-rata & 3 & 3 & 3 & 4 & 3,2 & 80,1 \\
\hline
\end{tabular}

Data pada tabel pada siklus I menunjukkan bahwa ada beberapa aspek yang diamati pada saat proses penulisan cerita berdasarkan pedoman obsevasi sebagai berikut:

1. Sudut Pandang. Berdasarkan data tabel menunjukkan rata-rata nilai 3 yang masuk dalam koatagori cukup.

2. Plot. Berdasarkan data tabel menunjukkan rata-rata nilai 3 yang masuk dalam katagori cukup. 
3. Gaya Bahasa. Berdasarkan data tabel menunjukkan rata-rata nilai 3 yang masuk dalam koatagori cukup.

Amanat. Berdasarkan data tabel menunjukkan rata-rata nilai 4 yang masuk dalam katagori baik.

4. Kesiapan mental. Berdasarkan data tabel menunjukkan rata-rata nilai 3,2 yang masuk dalam koatagori cukup.

\section{Deskripsi Siklus II}

Berdasarkan hasil penelitian Kemampuan Menulis Cerita, pengamatan (observasi) yang dilakukan pada siklus II maka diperoleh hasil penelitian disampaikan dalam bentuk tabel.

Tabel 4. Hasil Observasi Siklus II (setelah diadakan intensifikasi program)

\begin{tabular}{|c|c|c|c|c|c|c|c|}
\hline \multirow[b]{2}{*}{ No } & \multirow[b]{2}{*}{$\begin{array}{l}\text { Nama Guru } \\
\text { (Kode) }\end{array}$} & \multicolumn{4}{|c|}{ Unsur Cerita yang Dinilai } & \multirow[b]{2}{*}{$\begin{array}{c}\text { Kesiapan } \\
\text { Mental }\end{array}$} & \multirow[b]{2}{*}{$\begin{array}{l}\text { Hasil } \\
\text { akhir }\end{array}$} \\
\hline & & $\begin{array}{c}\text { Sudut } \\
\text { Pandang }\end{array}$ & Plot & $\begin{array}{c}\text { Gaya } \\
\text { Bahasa }\end{array}$ & Amanat & & \\
\hline 1 & A & 4 & 4 & 5 & 5 & 3 & 85 \\
\hline 2 & $\mathrm{~B}$ & 3 & 5 & 4 & 3 & 3 & 75 \\
\hline 3 & $\mathrm{C}$ & 3 & 5 & 3 & 5 & 3 & 85 \\
\hline 4 & $\mathrm{D}$ & 3 & 3 & 3 & 4 & 4 & 85 \\
\hline 5 & $\mathrm{E}$ & 3 & 3 & 3 & 4 & 3 & 80 \\
\hline 6 & $\mathrm{~F}$ & 3 & 3 & 4 & 4 & 3 & 85 \\
\hline 7 & $\mathrm{G}$ & 4 & 4 & 5 & 5 & 3 & 85 \\
\hline 8 & $\mathrm{H}$ & 3 & 5 & 4 & 3 & 3 & 75 \\
\hline 9 & I & 3 & 5 & 3 & 5 & 3 & 85 \\
\hline 10 & $\mathrm{~J}$ & 3 & 3 & 3 & 4 & 4 & 85 \\
\hline 11 & K & 3 & 3 & 3 & 4 & 3 & 80 \\
\hline 12 & $\mathrm{~L}$ & 3 & 3 & 4 & 4 & 3 & 85 \\
\hline 13 & $\mathrm{M}$ & 4 & 4 & 5 & 5 & 3 & 85 \\
\hline 14 & $\mathrm{~N}$ & 3 & 5 & 4 & 3 & 3 & 75 \\
\hline & Rata-rata & 3,2 & 3,8 & 3,7 & 4,2 & 3,2 & \\
\hline
\end{tabular}

Data pada tabel pada siklus II menunjukkan bahwa ada beberapa aspek yang diamati pada saat proses penulisan cerita berdasarkan pedoman obsevasi sebagai berikut:

1. Sudut Pandang. Berdasarkan data tabel menunjukkan rata-rata nilai 3,2 yang masuk dalam koatagori cukup.

2. Plot. Berdasarkan data tabel menunjukkan rata-rata nilai 3,8 yang masuk dalam koatagori baik.

3. Gaya Bahasa. Berdasarkan data tabel menunjukkan rata-rata nilai 3,7 yang masuk dalam koatagori baik.

4. Amanat. Berdasarkan data tabel menunjukkan rata-rata nilai 4,2 yang masuk dalam koatagori baik.

5. Kesiapan mental. Berdasarkan data tabel menunjukkan rata-rata nilai 3,2 yang masuk dalam koatagori cukup 


\section{Diskusi}

Penelitian tentang upaya meningkatkan kemampuan guru dalam menulis cerita melalui Workshop di SD Negeri Tenggilis Mejoyo I Surabaya Tahun Pelajaran 2021/2022 dilaksanakan dalam satu siklus dengan menerapkan intensifikasi program Satu Sekolah Satu Buku melalui Workshop dengan ciri sebagai berikut:

1. Mengumpulkan guru dalam satu ruangan

2. Peneliti mendatangkan nara sumber untuk memberikan informasi tetang kostruksi cerita.

3. Memberikan binaan secara klasikal

4. Penulis mengadakan diskudi dengan teman dalam 2 kelompok pengetahuan (Kelompok A dan Kelompok B)

5. Penelitian dapat berlangsung dengan baik karena situasi berlangsung terbuka dan kolaboratif.

Dengan menerapkan intensifikasi program Satu Sekolah Satu Buku melalui Workshop dalam menulis cerita aktivitaas dapat berlangsung dengan baik dan menyenangkan. Kerja sama dalam bentuk diskusi dapat menumbuhkan minat, sikap dan kemauan guru guru untuk melaksanakan tugasnya seperti halnya menulis cerita. Pada awalnya guru guru merasa tidak siap untuk menulis cerita dengan alasan terbatasnya waktu dan sulitnya menulis cerita sesuai kriteria, karena selama ini guru menulis cerita tidak sesuati kriteria. Tetapi setelah penyampaian materi oleh nara sumber yang berupa konstruksi cerita, menambah wawasan bagi guru guru dalam hal menulis cerita dan guru merasa perlu menulis cerita sesuai kriteria.

Berdasarkan data yang diperoleh pada siklus I maka hasil yang diperoleh pada intensifikasi Program Satu Sekolah Satu Buku melalui Workshop antara lain:

1. Aspek sudut pandang dengan rata-rata skor 3 menunjukkan bahwa guru telah memiliki sudut pandang yang baik sebagai bahan penting dalam penulisan kerangka cerita.

2. Aspek plot dengan rata-rata skor 2,9 menunjukkan bahwa guru cukup baik dalam mengalirkan cerita.

3. Aspek gaya bahasa dengan rata-rata 2,8 menunjukkan bahwa guru sudah memperhatikan gaya bahasa yang diperlukan dalam menyusun cerita yang baik.

4. Format amanat dengan rata-rata 4 menunjukkan bahwa guru guru dapat menyisipkan amanat dengan baik dalam cerita yang ditulis.

5. Aspek Kesiapan mental dengan rata-rata 3,1 menunjukan bahwa guru sudah bersiap dalam mengikuti Workshop dalam penulisan cerita.

Kemudian, berdasarkan data yang diperoleh pada siklus II maka dapat disimpulkan bahwa guru yang dianggap memiliki kemampuan di dalam menulis cerita apabila hasilnya memenuhi kriteria cerita yang layak seperti kesesuaian dengan unsur pembangun cerita, kesesuaian dengan indikator yang diukur (C1-C6), penggunaan Bahasa Indonesia yang baik dan benar dan sesuai dengan EYD Cerita dikatakan layak apabila minimal $65 \%$ kriteria bisa terpenuhi. Ini terbukti pada tabel siklus II dari 6 guru yang diteliti dalam penulisan cerita ini $100 \%$ guru sudah tuntas dalam menulis 
cerita profesional. Ini menunjukkan adanya peningkatan mutu dalam penulisan cerita oleh guru di SD Negeri Tenggilis Mejoyo I Surabaya Tahun Pelajaran 2021/2022.

\section{KESIMPULAN}

Berdasarkan analisis data, dari penelitian ini dapat ditarik kesimpulan bahwa intensifikasi Program Satu Sekolah Satu Buku melalui Workshop dalam menulis cerita sangat efektif. Sikap dan kemampuan guru di SD Negeri Tenggilis Mejoyo I Surabaya Tahun Pelajaran 2021/2022 meningkat setelah Workshop. Selain itu, juga dapat meningkatkan pula kemampuan guru di dalam menulis cerita secara profesional.

Hal ini terlihat pada kegiatan siklus kedua setelah intensifikasi Program Satu Sekolah Satu Buku melalui Workshop rata rata nilai yang diperoleh adalah 70,3. Cerita dikatakan layak apabila minimal $65 \%$ kriteria bisa terpenuhi. Dengan demikian telah dapat dinyatakan bahwa pada siklus pertama dan kedua $100 \%$ guru sudah mampu menulis cerita pada tahun pelajaran 2021/2022.

Karena adanya pengaruh positif terhadap intensifikasi Program Satu Sekolah Satu Buku melalui Workshop untuk menulis cerita baik dapat meningkatkan minat, motivasi maupun kemampuan guru khususnya dalam menulis cerita profesional maka melalui kesempatan ini penulis mengajukan beberapa saran agar dalam mengintensifkan program hendaknya menyelenggarakan Workshop agar kerja sama guru dan saling tukar informasi dapat terbina dengan baik dalam mewujudkan meningkatkan mutu sekolah.

\section{UCAPAN TERIMA KASIH}

Terimakasih saya ucapkan kepada pengawas SD dan Guru-guru di SDN Tenggilis Mejoyo I Surabaya yang telah memberikan kesempatan kepada peneliti dalam melaksanakan penelitian. Selain itu juga kepada seluruh stakeholder yang telah ikut berpartisipasi dalam melaksanakan penelitian ini.

\section{REFERENSI}

Aminuddin. 1987. Pengantar Apresiasi Karya Sastra. Bandung: Sinar Baru Algensindo

Antoro, Billy. 2017. Gerakan Literasi Sekolah dari Pucuk Hingga Akar (Sebuah Refleksi). Jakarta: Kemendikbud.

Arikunto, Suharsimi. 2004. Prosedur Penelitian. Yogyakarta: Rineka Cipta

Boediono. 1999. Jurnal Pendidikan dan Kebudayaan. Jakarta. Depdiknas

Diponegoro, Mohammad. 1994. Yuk, Nulis Karangan Fiksi Yuk. Yogyakarta: Pustaka Pelajar

Endraswara, Suwardi. 2003. Membaca, Menulis, Mengajarkan Sastra. Yogyakarta: Kota Kembang

Gie, The Liang. 2002. Terampil Mengarang. Yogyakarta:ANDI

Jabrohim, dkk. 2003. Cara Menulis Kreatif. Yogyakarta: Pustaka Pelajar

Suharianto, S. 1982. Dasar-Dasar Teori Sastra. Surakarta: Widya Duta 
Sumardjo, Jakob dan Saini K.M. 1986. Apresiasi Kesusastraan. Jakarta: Gramedia

Suyatno. 2004. Teknik Pembelajaran Bahasa dan Sastra. Surabaya: SIC

Tarigan, Henry Guntur. 1985. Menulis Sebagai Suatu Keterampilan Berbahasa. Bandung: Angkasa

Titik, dkk. 2003. Teknik Menulis Cerita Anak. Yogyakarta: PUSBUK

Zainal Aqib, 2002, Profesionalisme Guru Dalam Pembelajaran, SIC Surabaya. Online : https://www.floresnews.net/2020/08/satu-sekolah-menulis-satu-

buku.htmlhttps://setjen.kemdikbud.go.id/setjen/files/Buku\%20Gerakan\%20Literasi\%20Sekolah. pdf 